\title{
The Chemistry of Alliums
}

\author{
Martin C. H. Gruhlke and Alan J. Slusarenko * \\ Department of Plant Physiology, RWTH Aachen University, D-52056 Aachen, Germany; \\ Martin.Gruhlke@rwth-aachen.de \\ * Correspondence: alan.slusarenko@bio3.rwth-aachen.de
}

Received: 5 January 2018; Accepted: 6 January 2018; Published: 11 January 2018

Physiologically active sulfur-containing compounds produced by Allium spp. have long fascinated chemists, biochemists, and biologists. The major focus of attention has been on garlic compounds where the starting point for the complex chemistry is alliin (S-allylcysteine sulfoxide). Alliin is acted upon by the cysteine-S-lyase enzyme alliinase, when cell damage mixes substrate and enzyme. The first major volatile product is allicin (diallylthiosulfinate), giving crushed garlic its characteristic odor. Allicin decomposes readily to allylsulfenic acid (2-propensulfenic acid) and thioacreolin (2-propenethial), which enter into a cascade of reactions producing alkyl disulfides including diallyl disulfide and various polysulfanes, vinyl dithiins, and ajoene.

This special issue, "The Chemistry of Alliums", contains nine contributions that report on the chemistry and physiology of Allium organosulfur compounds. The paper by Eric Block et al. merits particular attention, as it introduces a new facet to the subject by reporting on the synthesis and physiological activity of fluorinated analogues of garlic organosulfur compounds [1]. Continuing the theme of taking garlic substances as lead compounds, Siyo et al., in an elegant molecular biological study, report on the activation of the unfolded protein response as the mechanism of cytotoxicity of the ajoene analogue bisPMB [2].

Garlic is consumed in many forms worldwide, and interest in the potential health benefits of aged, or 'black garlic', which no longer contains allicin but is enriched with several downstream metabolites, is increasing. Five contributions in this special issue relate to aged garlic and its sulfur-containing constituents. Ryu and Kang [3] contribute an up-to-date review on the reported physiological activities and constituents of aged black garlic, and Farrag et al. compare the effects of different drying methods in an MS-based metabolomics study [4]. Aged black garlic is enriched in S-allyl cysteine (SAC), and Tsukoa et al. report on the beneficial effects of SAC on pulmonary fibrosis in rats [5]. Kodera et al. report on the biological properties of the closely related S-1-propenyl-L-cysteine [6], and Pérez-Torres et al. report on the effect of the extracts of aged garlic cardiovascular function in rats exhibiting metabolic syndrome [7].

The assimilation mechanisms that plants use for $\mathrm{SO}_{4}{ }^{2-}$ can also be used for $\mathrm{SeO}_{4}{ }^{2-}$ or $\mathrm{SeO}_{3}{ }^{2-}$, and the sulfur-rich alliums are often good dietary sources of Se, which is frequently deficient in the human diet and is very important for antioxidative, protective enzymes, such as glutathione peroxidase. However, cultivated alliums can only synthesize and accumulate sulfur- and selenium-containing organic compounds if they have an adequate source of these elements during growth. González-Morales et al. investigate this aspect in their contribution to this special issue [8].

Lastly, returning full circle to allicin, in a paper that will hopefully be useful to allicin researchers worldwide, Albrecht et al. report a facile synthesis and purification procedure to achieve a good yield of highly pure product, based on the already-published favored method of oxidation of diallyl disulfide with a peracid catalyst. Furthermore, they show novel data clarifying the reaction mechanism and kinetics [9].

Thus, this special issue addresses a wide range of contemporary issues relating to the chemistry of alliums as well as the biological effects and potential uses of their organosulfur compounds and the derivatives thereof and will be of interest to students and researchers alike. 


\section{References}

1. Block, E.; Bechand, B.; Gundala, S.; Vattekkatte, A.; Wang, K.; Mousa, S.; Godugu, K.; Yalcin, M.; Mousa, S. Fluorinated Analogs of Organosulfur Compounds from Garlic (Allium sativum): Synthesis, Chemistry and Anti-Angiogenesis and Antithrombotic Studies. Molecules 2017, 22, 2081. [CrossRef] [PubMed]

2. Siyo, V.; Schäfer, G.; Hunter, R.; Grafov, A.; Grafova, I.; Nieger, M.; Katz, A.; Parker, M.; Kaschula, C. The Cytotoxicity of the Ajoene Analogue BisPMB in WHCO1 Oesophageal Cancer Cells is Mediated by CHOP/GADD153. Molecules 2017, 22, 892. [CrossRef] [PubMed]

3. Ryu, J.; Kang, D. Physicochemical Properties, Biological Activity, Health Benefits, and General Limitations of Aged Black Garlic: A Review. Molecules 2017, 22, 919. [CrossRef] [PubMed]

4. Farag, M.; Ali, S.; Hodaya, R.; El-Seedi, H.; Sultani, H.; Laub, A.; Eissa, T.; Abou-Zaid, F.; Wessjohann, L. Phytochemical Profiles and Antimicrobial Activities of Allium cepa Red cv. and A. sativum Subjected to Different Drying Methods: A Comparative MS-Based Metabolomics. Molecules 2017, 22, 761. [CrossRef] [PubMed]

5. Tsukioka, T.; Takemura, S.; Minamiyama, Y.; Mizuguchi, S.; Toda, M.; Okada, S. Attenuation of Bleomycin-Induced Pulmonary Fibrosis in Rats with S-Allyl Cysteine. Molecules 2017, 22, 543. [CrossRef] [PubMed]

6. Kodera, Y.; Ushijima, M.; Amano, H.; Suzuki, J.; Matsutomo, T. Chemical and Biological Properties of S-1-Propenyl-L-Cysteine in Aged Garlic Extract. Molecules 2017, 22, 570. [CrossRef] [PubMed]

7. Pérez-Torres, I.; Torres-Narváez, J.; Pedraza-Chaverri, J.; Rubio-Ruiz, M.; Díaz-Díaz, E.; del Valle-Mondragón, L.; Martínez-Memije, R.; Varela López, E.; Guarner-Lans, V. Effect of the Aged Garlic Extract on Cardiovascular Function in Metabolic Syndrome Rats. Molecules 2016, 21, 1425. [CrossRef] [PubMed]

8. González-Morales, S.; Pérez-Labrada, F.; García-Enciso, E.; Leija-Martínez, P.; Medrano-Macías, J.; Dávila-Rangel, I.; Juárez-Maldonado, A.; Rivas-Martínez, E.; Benavides-Mendoza, A. Selenium and Sulfur to Produce Allium Functional Crops. Molecules 2017, 22, 558. [CrossRef] [PubMed]

9. Albrecht, F.; Leontiev, R.; Jacob, C.; Slusarenko, A. An Optimized Facile Procedure to Synthesize and Purify Allicin. Molecules 2017, 22, 770. [CrossRef] [PubMed] 